\title{
Review on the Extent of Acid Soil in Ethiopia, Its Impact and Management Methods
}

\author{
Wegene Negese \\ Oromia Agricultural Research Institute, Haro Sabu Agricultural Research Center, P.O. Box 10, Haro sabu, \\ Oromia, Ethiopia
}

\begin{abstract}
Soil degradation is a global threat. Developing countries are more severely affected by soil degradation than developed countries. Ethiopia, one of the developing countries in eastern Africa, is highly threatened by soil degradation problems. Soil acidity is one of the main factors that limit and prevent profitable and sustained agricultural productivity in many parts of the world. The objective of this paper is to review the extent of acid soil distributions in Ethiopia, its impact on crop production and management practices. About $40.9 \%$ of the total arable land of Ethiopia is affected by soil acidity, from these $27.7 \%$ moderately to weak acids with $\mathrm{pH}$ 5.8-6.7 and $13.2 \%$ covered by strong to moderate acidic soils with $\mathrm{pH}$ less than 5.5. According to Ethio SIS, (2014) about $43 \%$ of the Ethiopian arable land is affected by soil acidity of these about $28.1 \%$ of soils in Ethiopia are dominated by strong acid soils ( $\mathrm{pH}$ 4.1-5.5). Most of investigators confirmed that the two fundamental factors that limit the fertility of acid soils are: nutrient deficiencies, e.g. phosphorus $(\mathrm{P})$, calcium $(\mathrm{Ca})$ and magnesium $(\mathrm{Mg})$ and the presence of phytotoxicity substances, e.g. soluble aluminium ( $\mathrm{Al}$ ) and manganese (Mn). To overcome these problems, different acid soil management has been implemented in the country. Thus many studies have been conducted with regards to Acid soil management which influences soil physical and chemical properties and crop yield directly or indirectly. Therefore, the aim of this seminor paper is to review different literature on the extent of acid soil in Ethiopia, its impacts on some selected chemical soil properties and management methods. Different studies showed that some soil chemical properties such as $\mathrm{pH}$, Ava_P, OC, CEC, Echangeable Acididy (EA), Excheanchable bases $(\mathrm{Ca}, \mathrm{Mg}, \mathrm{Na}$ and $\mathrm{K}$ ) and crop yields were improved in different agro ecologies by effects of liming and ISFM. Soil acidity problems also can be overcome by growing crop genotypes which are adapted to acid soil condition. Thus, for sustainable agricultural systems within smallscale farming in developing countries like Ethiopia, use of integrated soil fertlity management, liming and crop varieties tolerant to $\mathrm{Al}$ toxicity are the mechanisms used for management of acid soils.
\end{abstract}

Key note: Acidity, Lime, ISFM , Acid tolerant crop varieties

DOI: $10.7176 / \mathrm{JBAH} / 9-15-03$

Publication date: August $31^{\text {st }} 2019$

\section{INTRODUCTION}

Land degradation and low soil fertility are very common features of large parts of Sub-Saharan Africa (Vesterager et al., 2008). Soil degradation is caused by unsustainable land uses and management practices, and climate extremes (FAO, 2015). Approximately $50 \%$ of potentially arable land in Africa is currently under cultivation, of which 2000 million ha (23\% of agricultural land) are already of low soil fertility, and the soil fertility of the remaining arable lands continues to decline due to mismanagement (FAO, 2003; UNEP, 2004). According to FAO (2015) estimation, about $83 \%$ of rural people in Sub-Saharan Africa depend on the land for their livelihoods, but $40 \%$ of Africa's land resources are currently degraded. Furthermore, about $33 \%$ of soils are moderately to highly degrade due to erosion, nutrient depletion, acidification, salinisation, compaction and chemical pollution (FAO, 2015). The decline in soil fertility is especially severe in tropical soils. Monocropping, nutrient mining, unbalanced nutrient application, removal of crop residues from the fields and inadequate resupplies of nutrients have contributed to decline in crop yields (Nyamangara, 2001).

Soil degradation is also process that describes human-induced phenomena,which lowers the current and/or future capacity of the soil to support human life'(ISRIC, 1990). The ever-increasing human population is most challenging in developing countries because of soil degradation. For instance, in Sub-Saharan African countries, soil fertility depletion is the fundamental biophysical cause for declining per capital food production (Sanchez et al., 1997). The population of Ethiopia is currently growing at a faster rate and demands an increasing proportion of agricultural products. On the other hand, growth in food production is not in equal footings with population pressure. This challenge will continue as population pressure increases and degradation of soil resources is aggravated. The rate of soil quality degradation depends on land use systems, soil types, topography, and climatic conditions. Several works showed that inappropriate land use aggravates the degradation of soil physicochemical and biological properties (Saikhe et al., 1998; He et al., 1999). Maddonni et al.(1999) also reported that land use affects basic processes such as erosion, nutrient cycling, leaching and other similar physical and biochemical processes.

Soil acidity is one of the main factors that limit and prevent profitable and sustained agricultural 
productivity in many parts of the world (Sumner and Noble, 2003). It is estimated that approximately $50 \%$ of the worlds' arable soils are acidic and may be subjected to the effect of aluminum (Al) toxicity of which the tropics and subtropics account for $60 \%$ of the acid soils in the world (Sumner and Noble, 2003). The extent of soil acidity in Africa is difficult to quantify. Eswaran et al.(1997) estimated that $28.8 \%$ of the African continent has acid surface soils and $19.6 \%$ has sub soil acidity problems. In the tropics the soil acidity is aggravated by leaching or/and continuous removal of basic cations through crop harvest. About $40.9 \%$ of the Ethiopian total land is affected by soil acidity. Of this area, about $27.7 \%$ are dominated by moderate to weak acid soils ( $\mathrm{pH}$ in $\mathrm{KCl}$ of $4.5-5.5$ ), and around $13.2 \%$ are strong acid soils $(\mathrm{pH}$ in $\mathrm{KCl}$ of $<4.5$ and nearly one-third have aluminum toxicity problem (Mesfin, 2007). In humid and sub-humid area of Ethiopia, vast areas of land in the western, south-western, north-western and even the central highlands of the country which receive high rainfall are thought to be affected by soil acidity (Mesfin, 2007) attributed to various factors including continuous cropping (in many areas mono-cropping) without the use of the required inputs, the problem of soil acidity in the country is apparently increasing recently both in area coverage and severity of the problem. The major soil forming factors and management practices giving rise to the increase in soil acidity in the country involve climatic factors such as RF/temp, topographic factors, soil parent materials, intensive mono-cropping and lack of technological inputs in the peasant sector to mitigate the problem (Mesfin, 1998).

Soil acidity affects the growth of crops because acidic soil contain toxic levels of aluminum and manganese and characterized by deficiency of essential plant nutrients such as P,N, K, Ca, Mg, and Mo (Wang et al., 2006). At $\mathrm{pH}$ below five (5), aluminum is soluble in water and becomes the domination in the soil solution. In acid soils, excess aluminum primarily injures the root apex and inhibits root elongation (Sivaguru and Horst, 1998). The poor root growth leads to reduced water and nutrient uptake, and consequently crops grown on acid soils are confronted with poor nutrients and water availability. The negative effect of high levels of soluble aluminum on plants growth has been widely reported (Matsumoto, 2002; Langer et al., 2009). The net effect of which is reduced growth and yield of crops (Wang et al., 2006 ).

According to Angaw and Desta (1988), soil acidity severely affects the yields of many crops in the western, south-western and southern parts of high rainfall areas of Ethiopia. In these areas, the annual rainfall exceeds the potential evaporation. Leaching of cations in soils is most responsible for increased soil acidity (Schlede, 1989). The infertility of soils in these areas is attributed to excessive concentration of aluminum ( $\mathrm{Al}$ ), iron $(\mathrm{Fe})$ or manganese $(\mathrm{Mn})$ on one hand; and to deficiencies of calcium $(\mathrm{Ca})$, magnesium $(\mathrm{Mg})$, phosphorus $(\mathrm{P})$ and molybdenum (Mo) on the other (Mesfin, 1996). Soil fertility and its potential productivity are closely related to soil physicochemical properties, among which soil reaction (soil $\mathrm{pH}$ ) has the greatest share. As to the nature and deleterious effects of soil acidity, $\mathrm{Al}, \mathrm{Fe}$, and $\mathrm{Mn}$ become more soluble and hence their concentration on the exchange complex increases (Mesfin, 1996). The chemistry of these toxic elements in the soil is complex and affects the nutrient balance in soil solution. Among the soil chemical properties, available soil phosphorus, cation exchange capacity (CEC), exchangeable bases and available micronutrients are the most affected by soil acidity. To increase crop yields and reduce crop production risks associated with soil acidity, there is need to focus on soil amendment practices that target efficiency of nutrients use in soils especially phosphorus that is made unavailable chemically for plant uptake.

The The agronomic and management options to correct acid soils, improve nutrient use efficiency, and increase crop production on acidic soils include liming, application of organic materials, appropriate crop rotations and use of plant species and varieties tolerant to Al and Mn toxicity (Sanchez and Salinas, 1981). Liming acid soils is a general practice to reduce aluminum toxicity and is considered to many scientists as the first step towards providing a balanced nutrition for cultivated plants (Brown and Stecker, 2003; Essington, 2004). Therefore the objective of this paper is to review the extent of acid soil distributions in Ethiopia, its impact on crop production and management practices.

\section{METHODOLOGY OF REVIEW}

To the success of this work, different sources such as journals, proceedings, thesis works and reports related to the extent of acid soil in Ethiopia, its impact on crop production and management methods have been used.

\section{THE EXTENT OF ACID SOIL IN ETHIOPIA, ITS IMPACT CROP PRODUCTION AND MANAGEMENT METHODS}

\subsection{The Extent of Soil Acidity in Ethiopia and Its Causes}

Soil acidity is a serious agricultural and environmental problem that limits the growth of pasture and crops in many parts of the world including Latin America, North America, Asia, Africa, Europe and Australia (Baligar et al., 1993). Yang et al.(2012) stated that approximately $43 \%$ of the world's tropical land area is classified as acidic, comprising of about $68 \%$ of tropical America, $38 \%$ of tropical Asia, and $27 \%$ of tropical Africa. Acidic soils cover a total of 1.66 billion hectares (ha) in 48 developing countries, while the total area affected by soil acidity is about 4 billion hectare (Von Uexkull and Mutert, 1995). Tropical and sub-tropical regions as well as 
areas with moderate climatic conditions are mostly affected by soil acidity.

According to Schlede (1989), acid soils are spreading and occupying larger area of cultivated land in Ethiopia. Different reports have indicated that there is significant soil acidity coverage in Ethiopia (World Bank, 1995; Wassie and Shiferaw, 2009). Soil acidity is estimated that about $40.9 \%$ of the total arable land of Ethiopia is affected by soil acidity (Abdenna et al., 2007) which covers $95 \%$ of the cropped area and contain almost $85 \%$ of the Ethiopian population.

The total area of Ethiopia is 111.8 million hectare out of these only 79 million of hectare is suitable for agriculture. Of this soil, about $27.7 \%$ are dominated by moderate to weak acid soils ( $\mathrm{pH}$ in $\mathrm{KCl}$ of $4.5-5.5$ ), and around $13.2 \%$ are strong acid soils $(\mathrm{pH}$ in $\mathrm{KCl}$ of $<4.5$ and nearly one-third have aluminum toxicity problem (Mesfin, 2007).

The problem is especially significant in the northwestern, western, southern and central regions of the country. Western and southern parts of Ethiopia, are dominantly covered by soils with $\mathrm{pH}<5.5$ (Schlede, 1989). However, moderately acidic soils $(\mathrm{pH}$ 5.5- 6.5) are distributed through much of the rest of the country (Taye, 2007). In these areas, the annual rainfall exceeds the potential evaporation. Leaching of cations in soils is most responsible for increased soil acidity (Schlede, 1989). According to Ethio SIS, (2014) about 43\% of the Ethiopian arable land is affected by soil acidity of these about $28.1 \%$ of soils in Ethiopia are dominated by strong acid soils ( $\mathrm{pH}$ 4.1-5.5) (Figure 1). Strongly acidic soils are usually infertile because of the possible $\mathrm{Al}$ and $\mathrm{Mn}$ toxicities, and $\mathrm{Ca}, \mathrm{Mg}, \mathrm{P}$, and molybdenum (Mo) deficiencies (Barber, 1984).

In Ethiopia, soil acidity increase involves climatic factors, such as rainfall, temperature, and topographic factors. Soil acidity in Ethiopia often developed in regions where excessive rainfall coupled with unfavorable temperature and precipitation is high enough to leach appreciable amounts of exchangeable basic ions like calcium $(\mathrm{Ca})$, magnesium $(\mathrm{Mg})$, sodium $(\mathrm{Na})$ and potassium $(\mathrm{K})$ from the surface of soils (Mesfin 2007). Its severity is extremely variable due to the effects of parent materials, land form, vegetation and climate pattern (Achalu et al., 2012).

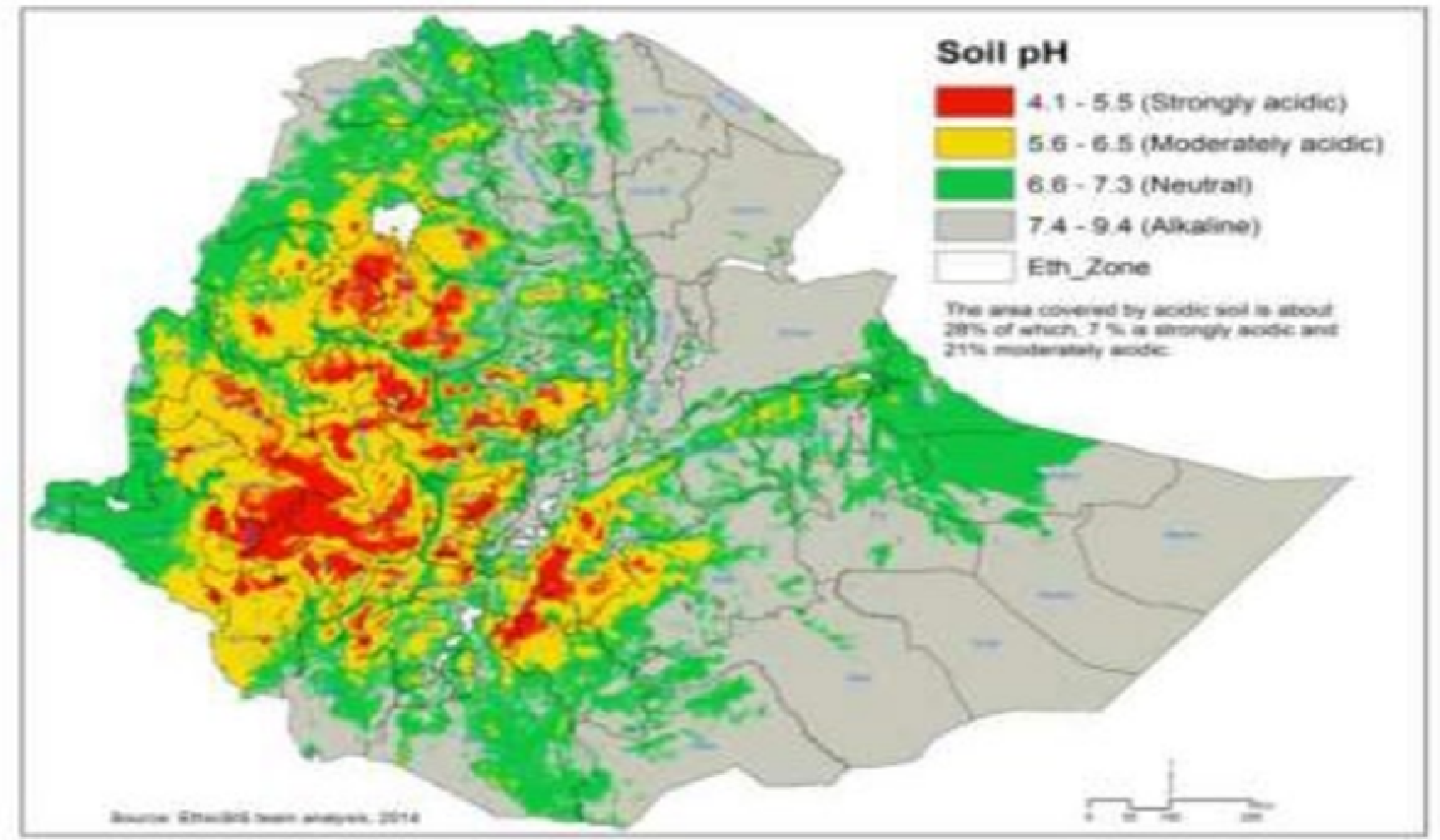

Figure 1. Extent and Distribution of Soil Acidity in Ethiopia (Ethio SIS, 2014)

\subsection{Impacts of Soil Acidity on Crop Production}

Acidity produces complex interactions of plant growth - limiting factors involving physical, chemical, and biological properties of soil (Robarge, 2008). Soil erosion and low water - holding capacity are major physical constraints for growing crops on tropical soils. Calcium, magnesium, and phosphorous deficiencies or un availabilities and aluminum toxicity are considered major chemical constraints that limit plant growth on acid soils (Menzies, 2003). Among biological properties, activities of beneficial microorganisms are adversely affected by soil acidity, which has profound effects on the decomposition of organic matter, nutrient mineralization, and immobilization, uptake, and utilization by plants, and consequently on crop yields (Fageria, 2009). 
The two fundamental factors that limit the fertility of acid soils: i) nutrient deficiencies, e.g. phosphorus (P), calcium $(\mathrm{Ca})$ and magnesium $(\mathrm{Mg})$ and ii) the presence of phytotoxicity substances, e.g. soluble aluminium $(\mathrm{Al})$ and manganese (Mn) (Mesfin, 2007). Aluminium (Al) in acid soil will be solubilized into ionic forms, especially when the soil $\mathrm{pH}$ falls to lower than five (5). These ionic forms of $\mathrm{Al}$ have been shown to be very toxic to plants, initially causing inhibition of root elongation by destroying the cell structure of the root apex and thus affecting water and nutrient uptake by the roots; as a consequence, plant growth and development is seriously hin dered (Barber, 2001). On the other hand, phosphorous (P) is easily fixed by clay minerals that are rich in acids soils, including various iron oxides and kaolinite, and hence rendering it unavailable for root uptake (Mesfin, 2007). Thus, Al toxicity and $\mathrm{P}$ deficiency are considered to be two main constraints for crop production in acid soil (Barber, 2001).

Soil acidity affects the growth of crops because acidic soil contain toxic levels of aluminum and manganese and characterized by deficiency of essential plant nutrients such as P,N, K, Ca, Mg, and Mo (Wang et al., 2006). At $\mathrm{pH}$ below five (5), aluminum is soluble in water and becomes the domination in the soil solution. In acid soils, excess aluminum primarily injures the root apex and inhibits root elongation (Sivaguru and Horst, 1998). The poor root growth leads to reduced water and nutrient uptake, and consequently crops grown on acid soils are confronted with poor nutrients and water availability. The net effect of which is reduced growth and yield of crops ( Wang et al., 2006). The productivity of acid soils is limited by the presence of toxic levels of $\mathrm{Al}$ and $\mathrm{Mn}$ and deficiency of nutrients such as P, Ca, Mg and Mo (Brady and Weil, 2014). The solubility and availability of important nutrients to plants is closely related to the $\mathrm{pH}$ of the soil ( Marschner, 2011).
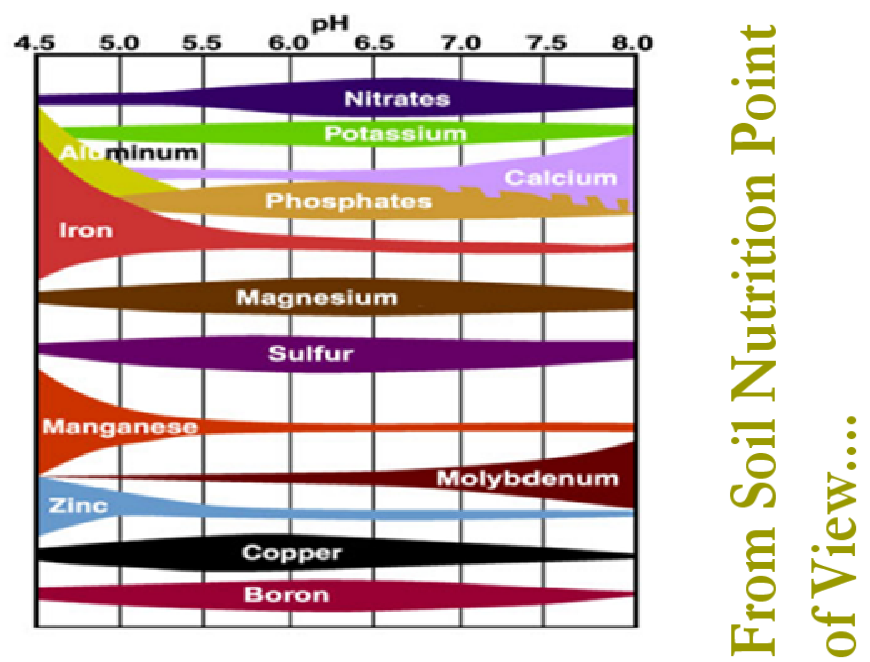

\section{Most nutrients are highest and most toxins are lower at $\mathrm{pH}$ 5.5-7.0}

Figure 2. Effect of soil PH on soil nutrient availability

\subsection{Management Option of Soil Acidity Problems}

Major constraints to crop production in tropical acid soils are toxicities of $\mathrm{Al}$ and $\mathrm{Mn}$ and deficiencies of $\mathrm{Ca} / \mathrm{Mg}$ (Mesfin, 2007). In order to have successful agriculture in these regions, acid soil stresses need to be alleviated. The agronomic and management options to correct acid soils, improve nutrient use efficiency,and increase crop production on acidic soils include liming, application of organic materials, appropriate and crop mixtures, and use of plant species and varieties tolerant to Al and Mn toxicity (Sanchez and Salinas, 1981).

\subsubsection{Liming}

Liming of acidic soils to a lower $\mathrm{pH}$ neutralize exchangeable $\mathrm{Al}^{3+}$ and $\mathrm{Mn}^{2+}$ toxicity ,while supplying $\mathrm{Ca}$ and (dolomite lime) magnesium. This generally improves phosphorous uptake by plants (Sanchez and Vehara, 1980). By reducing Al toxicity in acidic soils, liming often increase the effective crop rooting depth, allowing a bigger soil volume to be explored for nutrients and water by the crop (Fageria and Baligar, 2008). Number of liming materials includes crushed limestone $\left(\mathrm{CaCO}_{3}\right)$, dolomatic lime $\left(\mathrm{CaMgCO}_{3}\right)$, Slaked lime $\left(\mathrm{Ca}(\mathrm{OH})_{2}\right)$, quick lime $(\mathrm{CaO})$ etc., can be used to minimize soil acidity. Studies have shown that apart from reducing the acidity of the soil by counter acting the effects of excess $\mathrm{H}^{+}$and $\mathrm{Al}^{3+}$ ions (Fageria and Baligar, 2003), according to this author, liming also has several other benefits including, its ability to reduce the toxicity effects of some microelements by lowering their concentrations while increasing the availability of plant nutrients such as $\mathrm{Ca}, \mathrm{P}, \mathrm{Mo}$, and $\mathrm{Mg}$ in the soil and reducing the solubility of heavy metals. Crops absorb most of these nutrient elements particularly Ca, $\mathrm{P}$, and $\mathrm{Mg}$ in substantial amounts and therefore by increasing their amounts in soil, crop yields can be significantly improved. Liming also stimulates microbial activity and enhances $\mathrm{N}$ fixation and $\mathrm{N}$ mineralization and hence, legumes are highly benefited from liming (Fageria and Baligar, 2008). Therefore, Liming is a major and effective practice to overcome soil acidity constraints and improve crop production on acid soils. Lime is 
called the foundation of crop production or "workhorse", in acid soils (Fageria and Baligar, 2008).

3.3.1.1.Potential effects of lime on some chemical properties of acid soils and grain yield

3.3.1.1.1. Soil reaction $(\mathrm{pH})$

Soil reaction is expressed in terms of $\mathrm{pH}$ indicating whether the soil is acidic, alkaline or neutral. Soil $\mathrm{pH}$ measures the molar activity (concentration) of hydrogen ions in the soil solution. The solubility and availability of important nutrients to plants is closely related to the $\mathrm{pH}$ of the soil (Marschner, 2011). By increasing soil $\mathrm{pH}$, liming makes other nutrients more available, and prevents $\mathrm{Al}$ and $\mathrm{Mn}$ from being toxic to plant growth (Yao et al., 2010).

According to the study conducted by Buni (2014) soil $\mathrm{pH}$ increased from 5.03 to 6.72 due to the application of $3.75 \mathrm{t} \mathrm{ha}^{-1}$ lime (Table 1). Another study conducted by Moges et al. (2018) shows that Application of lime and $\mathrm{P}$ fertilizer brought a change on $\mathrm{pH}$. The mineral $\mathrm{P}$ fertilizer application has no effect on the $\mathrm{pH}$ compared to the control. Similarly, Dessalegn et al. (2018) found that soil pH increased due to the application to different lime as compared to control (Table 1). The rise in $\mathrm{pH}$ and reduction of soil exchangeable acidity is associated with the presence of basic cations $\left(\mathrm{Ca}^{2+}\right.$ and $\left.\mathrm{Mg}^{2+}\right)$ and anions $\left(\mathrm{CO}_{3}{ }^{2-}\right)$ in lime that are able to exchange $\mathrm{H}^{+}$from exchange sites to form $\mathrm{H}_{2} \mathrm{O}+\mathrm{CO}_{2}$. Cations occupy the space left behind by $\mathrm{H}^{+}$on the exchange leading to the rise in $\mathrm{pH}$ (Fageria et al., 2007). Kisinyo et al. (2012) also reported that soil pH increase in lime treatment as a result of $\mathrm{H}^{+}$ and $\mathrm{Al}^{3+}$ ions displacement from soil adsorption sites by $\mathrm{Ca}^{2+}$ ions contained in lime. Liming of acid soils raises soil $\mathrm{pH}$, which in turn releases phosphate ions precipitated with $\mathrm{Al}$ and $\mathrm{Fe}$ ions thus making $\mathrm{P}$ available for plant uptake (Achalu et al., 2012).

3.3.1.1.2. Exchangeable acidity

Exchangeable acidity consists of aluminum or iron, as well as any exchangeable $\mathrm{H}$ that may be present in the exchange sites (Bohn et al., 2001). Exchangeable acidity in soils is almost entirely due to $\mathrm{Al}^{3+}$ ions. This is because only $\mathrm{Al}^{3+}$ is a common exchangeable cation in moderately to strongly acidic soils (Bohn et al., 2001).

Exchangeable Al normally occurs in significant amounts only at soil $\mathrm{pH}$ values less than about 5.5. As the $\mathrm{pH}$ of the soil solution increases, first one and then two of the $\left(\mathrm{OH}_{2}^{-}\right)$groups lose a hydrogen ion to form an $(\mathrm{OH})$ ion, resulting in di- or monovalent hydroxyl-aluminum cations. All three of these cation species are adsorbed by negatively charged exchange sites and thus reduce the cation exchange capacity (CEC) of soil (Bohn et al., 2001). The fraction of exchange sites occupied by $\mathrm{Al}\left(\mathrm{H}_{2} \mathrm{O}\right)_{6}{ }^{3+}$ and its hydrolysis products can become large once the soil $\mathrm{pH}$ falls below 5.5. Furthermore, as the $\mathrm{pH}$ is lowered, the concentration of soluble aluminum, which is toxic, increases (McBride, 1994). In addition to direct toxic effects of soluble $\mathrm{Al}^{3+}$ to plants, it replaces the plant nutrient cations such as $\mathrm{Ca}$ and $\mathrm{Mg}$, and simultaneously acts as strong absorber of phosphate (Marschner, 2002). Liming soils to reduce toxic levels of A1 is recognized as necessary for optimal crop production on acid soils.

The experiment conducted by Buni (2014) shows that exchangeable acidity (EA) was significantly reduced due to the application of lime on Nitisol with an inherent property of high $\mathrm{P}$ fixation (Table 1). This decrease may be ascribed to the increased replacement of $\mathrm{Al}$ by $\mathrm{Ca}$ in the exchange site and by the subsequent precipitation of $\mathrm{Al}$ as $\mathrm{Al}(\mathrm{OH})_{3}$, as the soil was limed (Havlin et al., 1999). Moreover, an increase in soil $\mathrm{pH}$ results in precipitation of exchangeable and soluble $\mathrm{Al}$ as insoluble $\mathrm{Al}$ hydroxides thus reducing concentration of $\mathrm{Al}$ in soil solution. Moges et al. (2018) also showes that Application of lime and P fertilizer brought a change on exchangeable acidity. The mineral $\mathrm{P}$ fertilizer application has no effect on exchangeable acidity compared to the control (Table 1). Effiong and Okon (2009) also reported that treated acidic soils with various liming materials for one month generally reduced exchangeable acidity among which $\mathrm{CaCO}_{3}$ used as a liming material showed up to $68 \%$ reduction of exchangeable acidity of the soils. Another study conducted by Dessalegn et al. (2018) also shows application of different splits of lime significantly reduced exchangeable acidity to the minimum level. Application of lime, irrespective of the rate used, significantly reduced the exchangeable acidity compared to the control (Table 1). This is to be expected because lime is known to increase the soil $\mathrm{pH}$, hence precipitating $\mathrm{Al}$ as $\mathrm{Al}(\mathrm{OH})_{3}$ (Hue, 2004).

3.3.1.1.3. Available phosphorus

Phosphorus deficiency problems are compounded by widespread high phosphorus fixation capacity of acid soils (Somani, 1996). Since elemental P is very reactive chemically; it is not present in the pure state in nature. It is found only in chemical combinations with other elements (Gupta, 2000). The extent of inorganic P fixation depends on many factors, most importantly soil $\mathrm{pH}$. In acidic soils, inorganic P precipitates as Fe/Al-P secondary minerals and/or is adsorbed to the surfaces of Fe/Al oxides and clay minerals (Havlin et al., 1999). Cheng et al. (1999) observed that up to $98 \%$ of applied phosphate was converted into unavailable forms in acid soils within very short periods. Application of lime to acidic soils is generally credited for increasing the availability of $P$.

The experiment conducted by Buni (2014) shows that liming significantly increased available P (Table 1). Similarly, Moges et al. (2018) also showes that Application of lime and P fertilizer brought a change on vailable $\mathrm{P}$ (Table 1). Liming of acid soils raises soil $\mathrm{pH}$, which in turn releases phosphate ions precipitated with $\mathrm{Al}$ and Fe ions thus making $P$ available for plant uptake (Achalu Chimdi et al., 2012). 


\subsection{Cation exchangeable capacity}

The cation exchange capacity (CEC) of a soil represents the total quantity of negative charge available to attract cations in the soil solution. It is one of the most important chemical properties of soils as it strongly influences nutrient availability (Havlin et al., 1999). The CEC of highly weathered soils is $\mathrm{pH}$ dependant, and it is a function of the constituent minerals and organic matter. Under such soil, the CEC is increased as the $\mathrm{pH}$ of the soil increased by liming.

According to study conducted by Buni (2014) the highest and the lowest values of CEC were observed under the highest lime treated and the control plots, respectively (Table 1). The increase in CEC due to liming could be attributed to the change in $\mathrm{pH}$ and reduction of exchangeable acidity which in turn increased the exchange sites of the soil. Generally liming raises soil $\mathrm{pH}$, base saturation and reduces $\mathrm{Al}^{3+}$ concentration.

Table 1. Potential effects of lime on some chemical properties of acid soils

\begin{tabular}{|c|c|c|c|c|c|c|}
\hline $\begin{array}{l}\text { Treatments (Lime t } \\
\text { ha }^{-1} \text { ) }\end{array}$ & $\begin{array}{l}\text { pH } \\
\left(\mathbf{H}_{2} \mathbf{0}\right)\end{array}$ & $\begin{array}{l}\mathrm{EA}(\mathbf{m g} \\
\left.\mathrm{kg}^{-1}\right)\end{array}$ & $\begin{array}{l}\mathbf{P}(\mathbf{m g} \\
\left.\mathrm{kg}^{-1}\right)\end{array}$ & $\begin{array}{l}\operatorname{CEC}(\mathrm{Cmol}(+) \\
\mathrm{kg}^{-1)}\end{array}$ & Study site & Auther(s) \\
\hline Control & $5.03^{d}$ & $0.97^{a}$ & $5.36^{\mathrm{b}}$ & $19.18^{\mathrm{d}}$ & Southern & Buni, 2014 \\
\hline 1.25 & $5.64^{\mathrm{c}}$ & $0.75^{b}$ & $6.70^{\mathrm{a}}$ & $25.21^{\mathrm{c}}$ & Ethiopia & \\
\hline 2.50 & $6.14^{\mathrm{b}}$ & $0.51^{\mathrm{c}}$ & $7.04^{\mathrm{a}}$ & $31.49^{b}$ & & \\
\hline 3.75 & $6.72^{\mathrm{a}}$ & $0.36^{\mathrm{c}}$ & $6.67^{\mathrm{a}}$ & $33.34^{\mathrm{a}}$ & & \\
\hline $\operatorname{LSD}(0.05)$ & 0.014 & 0.21 & 0.94 & 0.738 & & \\
\hline $\mathrm{CV}(\%)$ & 3.01 & 6.43 & 2.04 & 6.24 & & \\
\hline Control & 5.04 & 0.96 & 8.95 & 18.76 & North shewa & Moges et \\
\hline 4 tone lime & 5.51 & 0.35 & 15.66 & 17.29 & Zone, & al., 2018 \\
\hline 6 tone lime & 5.64 & 0.19 & 16.77 & 17.11 & Amhara & \\
\hline $20 \mathrm{~kg} \mathrm{P}$ & 5.07 & 0.89 & 19.38 & 18.96 & & \\
\hline 20/4 P lime & 5.59 & 0.18 & 20.05 & 18.02 & & \\
\hline 20/6 P lime & 5.86 & 0.14 & 26.94 & 17.21 & & \\
\hline $30 \mathrm{~kg} \mathrm{P}$ & 5.09 & 0.78 & 22.34 & 18.67 & & \\
\hline 30/4 P lime & 5.44 & 0.32 & 28.34 & 17.09 & & \\
\hline 30/6 P lime & 5.79 & 0.16 & 30.43 & 16.84 & & \\
\hline $40 \mathrm{~kg} \mathrm{P}$ & 5.11 & 0.74 & 24.62 & 18.82 & & \\
\hline 40/4 P lime & 5.49 & 0.25 & 29.23 & 17.26 & & \\
\hline 40/6 P lime & 5.72 & 0.18 & 31.9 & 17.08 & & \\
\hline Mean & 5.45 & 0.43 & 23.24 & 17.76 & & \\
\hline Control & $5.0 \mathrm{~b}$ & $1.4 \mathrm{a}$ & $2.2 \mathrm{c}$ & & Asosa & Dessalegn \\
\hline Full dose of lime & $5.7 \mathrm{a}$ & $0.8 \mathrm{~b}$ & $2.8 \mathrm{bc}$ & & & Temane $e t$ \\
\hline $50 \%$ lime each year & $5.9 \mathrm{a}$ & $0.4 \mathrm{c}$ & $3.2 b$ & & & al., 2018 \\
\hline $33 \%$ lime each year & $5.8 \mathrm{a}$ & $0.6 b c$ & $2.9 \mathrm{bc}$ & & & \\
\hline $25 \%$ lime each year & $5.8 \mathrm{a}$ & $0.7 b c$ & $4.2 \mathrm{a}$ & & & \\
\hline $\operatorname{LSD}(0.05)$ & 0.4 & 0.4 & 0.9 & & & \\
\hline $\mathrm{CV}(\%)$ & 5.82 & 39.3 & 24.5 & & & \\
\hline
\end{tabular}

Soil pH; Ex.Ac, exchangeable acidity; Av.P, available P; CEC, cation exchange capacity.

3.3.1.1.5. Exchangeable bases ( $\mathrm{Ca}, \mathrm{Mg}, \mathrm{K}$ and $\mathrm{Na}$ )

The most common cations associated with $\mathrm{CEC}$ are $\mathrm{Al}^{3+}, \mathrm{H}^{+}, \mathrm{Ca}^{2+}, \mathrm{Mg}^{2+} \mathrm{K}^{+}, \mathrm{NH}_{4}{ }^{+}$and $\mathrm{Na}^{+}$. Except $\mathrm{Al}^{3+}$, most of the exchangeable cations are plant nutrients. The removal of base cations, especially $\mathrm{Ca}$ and $\mathrm{Mg}$, by leaching and erosion results in their replacement by acidic cations like $\mathrm{H}, \mathrm{Al}$ and $\mathrm{Fe}$ on exchange sites and in the soil solution (Johnston, 2004).

Tigist (2017) found an increase in exchangeable bases ( $\mathrm{Ca}, \mathrm{Mg}, \mathrm{K}$ and $\mathrm{Na}$ ) with an increasing lime rates when compared with contrlol (Table 2). Similarly Abdissa (2018) also reported that increased soil exchangeable bases as a result of lime application might be attributed to increase in soil $\mathrm{pH}$ which in turn may have increased exchangeable bases availability in the soil (Table 2). The results are in agreement with Andric et al. (2012) who reported that soil exchangeable bases increased when acidic soil was amended by lime and manure. 
Table 2. Effect of limes on soil exchangeable base

\begin{tabular}{lllllll}
\hline Treatment & \multicolumn{2}{l}{ Exchangeable bases $\left(\mathbf{c m o l}(+) \mathbf{~ k g}^{-\mathbf{1}}\right)$} & & Study site & Author(s) \\
\cline { 2 - 5 } & $\mathbf{C a}$ & $\mathbf{M g}$ & $\mathbf{K}$ & $\mathbf{N a}$ & Asosa & Yigist, 2017 \\
\hline Control & 4.80 & 0.84 & 0.74 & 0.10 & & \\
$1.62 \mathrm{t} \mathrm{ha}^{-1}$ Lime & 5.20 & 3.10 & 1.18 & 0.30 & & \\
$3.26 \mathrm{t} \mathrm{ha}^{-1}$ Lime & 5.20 & 3.59 & 1.18 & 0.26 & & \\
$4.90 \mathrm{t} \mathrm{ha}^{-1}$ Lime & 6.24 & 3.94 & 1.18 & 0.17 & & Abdissa \\
\hline Control & 3.5 & 1.52 & 0.25 & 0.16 & East wollega & Bekele ,2018 \\
$2 \mathrm{t} \mathrm{ha}^{-1}$ Lime & 4.5 & 1.65 & 0.31 & 0.78 & & \\
$4 \mathrm{t} \mathrm{ha}^{-1}$ Lime & 5.2 & 1.88 & 0.41 & 0.90 & & \\
$6 \mathrm{t} \mathrm{ha}^{-1}$ Lime & 5.9 & 3.09 & 0.42 & 0.97 & & \\
\hline
\end{tabular}

3.3.1.1.6. Grain yield

According to Desalegn et al. (2017) the combined application of $1.65 \mathrm{t} \mathrm{lime} \mathrm{ha}^{-1}$ and $30 \mathrm{~kg} \mathrm{P}$ ha ${ }^{-1}$ resulted in $133 \%$ more grain yields of barley than the control (without $\mathrm{P}$ and lime) (Figure 3 a). Application of 0.55, 1.1, 1.65 and $2.2 \mathrm{t}^{2}$ lime ha ${ }^{-1}$ decreased $\mathrm{Al}^{3+}$ by $0.88,1.11,1.20$ and 1.19 mill equivalents per $100 \mathrm{~g}$ of soil, and increased soil $\mathrm{pH}$ by $0.48,0.71,0.85$ and 1.1 units, respectively (Figure 3 b,c). Similarly Mahler et al. (1988) reported that yields of pea could be increased by $30 \%$ due to lime application to soils. Yield increments showed direct relationship with the soil $\mathrm{pH}$ values and inverse relationship with exchangeable acidity, i.e. as the $\mathrm{pH}$ increased the yield also increased, but as the exchangeable acidity decreased the yield increased and vice versa.

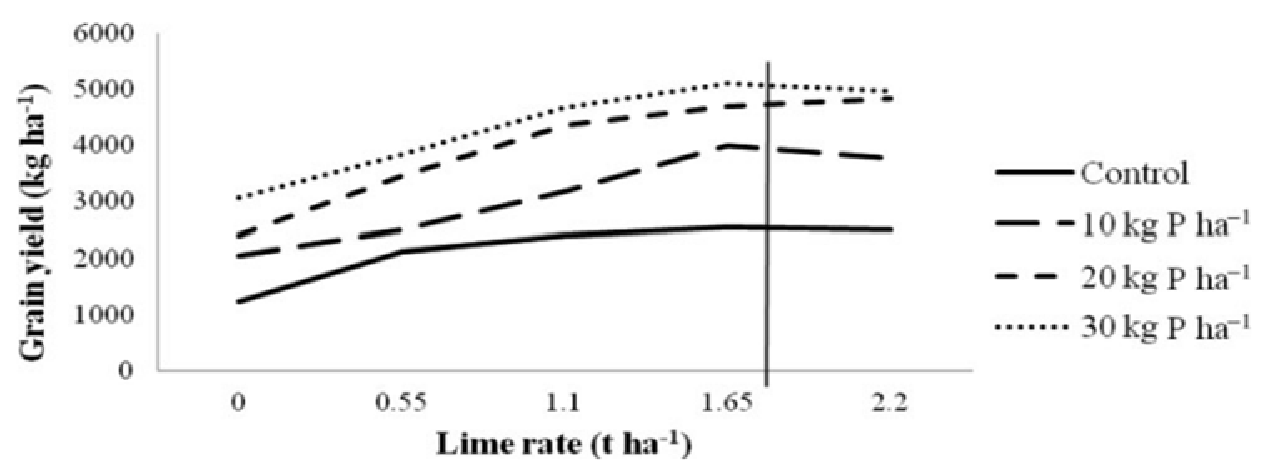

b)

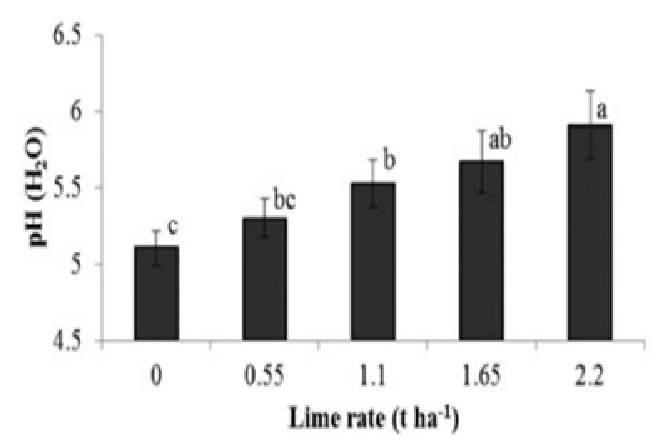

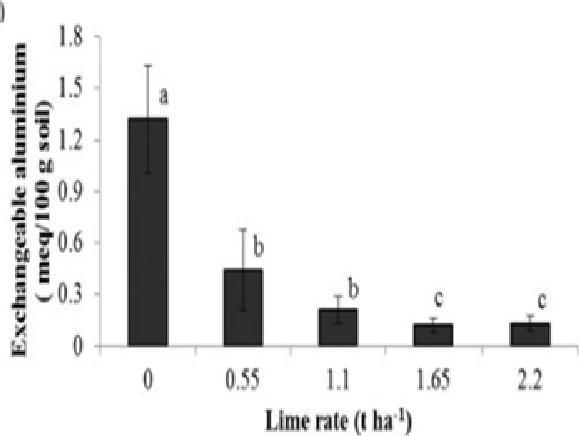

Source: Temesgen Desalegn et al., 2017

Figure 3. Barley grain yield: Interaction between rate of lime and rate of $\mathrm{P}$ applied.

Another experiment conducted by Dessalegn et al. (2018) on split application of lime also indicates that combined over three years grain yield of soybean recorded from control was significantly lower than the other treatments (Table 3). The highest grain yield of soybean obtained by application of $25 \%$ of split application of lime gives comparable yield with full dose of lime and 50\% of split applied lime. Therefore, from this result, we generalize that split application of lime could give relatively comparable yield when compaired with full dose application and could be a good option for poor small holder farmers. 
Table 3. Soybean seeds per yield and grain yield as influenced by split application of lime

\begin{tabular}{lll}
\hline Treatments & SPP & $\mathbf{G Y}\left(\mathbf{k g ~ h a}^{-1}\right)$ \\
\hline Control & $2.3 \mathrm{~b}$ & $701.3 \mathrm{c}$ \\
Full dose of lime & $2.8 \mathrm{ab}$ & $1031.6 \mathrm{ab}$ \\
$50 \%$ lime each year & $3.2 \mathrm{a}$ & $1178.0 \mathrm{a}$ \\
$33 \%$ lime each year & $2.9 \mathrm{a}$ & $926.1 \mathrm{~b}$ \\
$25 \%$ lime each year & $2.9 \mathrm{a}$ & $975.5 \mathrm{ab}$ \\
\hline LSD $(0.05)$ & 0.54 & 216.7 \\
\hline CV $(\%)$ & 20.2 & 23.5 \\
\hline SPP $=$ seed per pod, GY= Grain Yield & &
\end{tabular}

Source: Dessalegn Tamene et al., 2018

Similary, Agegnehu et al. (2006) reported that the application of lime at the rates of 1, 3 and $5 \mathrm{tha}^{-1}$ resulted significantly in linear response with mean faba bean seed yield advantages of 45,77 and $81 \%$ over the control (Figure 4). Generally, this might be with successive increase in the amounts of lime, grain yields increases with increase in soil $\mathrm{pH}$ and corresponding decrease in exchangeable $\mathrm{Al}^{3+}$ of the soil.

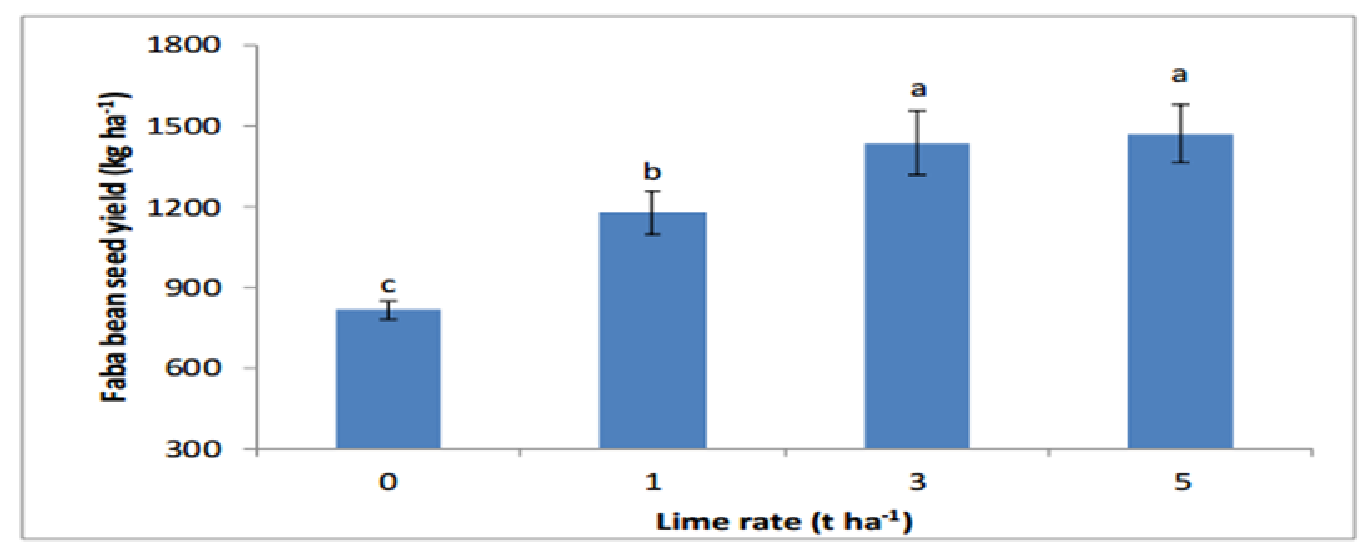

$L S D$ at $5 \%=192$, Error bars represent \pm 1 SE. Source: Agegnehu et al. (2006)

Figure 4. Effects of lime application rates on grain yield of faba bean

\subsubsection{Management of acidic soil using integrated soil fertility management (ISFM)}

Integrated soil fertility management (ISFM) is one of the approaches to manage and improve soil health and fertility status ( Agegnehu and Amede, 2017 ). It is one of the components of the management of acid soils. Farmyard manure (FYM) and crop residues are among organic plant nutrient sources, which could ameliorate the physical and chemical properties of soils. For example, Lal (2009) indicated that returning crop residues to soil as amendments is essential for recycling plant nutrients (20-60 $\mathrm{kg}$ of N, P, K, Ca per Mg of crop residues) amounting to 118 million $\mathrm{Mg}$ of $\mathrm{N}, \mathrm{P}, \mathrm{K}$ in residues produced annually in the world (83.5\% of world's fertilizer consumption). In acid soils, where $\mathrm{P}$ fixation is a problem application of FYM releases a range of organic acids that can form stable complexes with $\mathrm{Al}$ and $\mathrm{Fe}$ thereby blocking the $\mathrm{P}$ retention sites, and as a result, the availability and use efficiency of P is improved (Agegnehu and Amede, 2017 ).

The addition of organic fertilizers to acid soils has been effective in reducing phytotoxic levels of $\mathrm{Al}$ resulting in yield increases. The major mechanisms responsible for these improvements are thought to be the formation of organo- $\mathrm{Al}$ complexes that render the $\mathrm{Al}$ less toxic or direct neutralization of $\mathrm{Al}$ from the increase in $\mathrm{pH}$ caused by the organic matter.

The management of acid soils through integrated soil fertility and plant nutrient management not only improve the yields of crops but also the chemical properties of soils. Regular applications of organic residues can induce a long-term increase in SOM and nutrient content. According to Haynes and Mokolobate (2001), complexation of Al by the newly-formed organic matter tends to reduce the concentrations of exchangeable and soluble Al. As organic residues decompose, $\mathrm{P}$ is released and can be adsorbed to oxide surfaces. This can reduce the extent of adsorption of subsequently added $\mathrm{P}$ thus increasing $\mathrm{P}$ availability. The possible alternative of using organic sources such as crop residues, manures, compost and biochar are substitutes for lime (Sharma et al., 1990; Agegnehu and Amede, 2017).

The practical implication of these processes is that organic residues may be used as a strategic tool to reduce the rates of lime and fertilizer P required for optimum crop production on acidic, P-fixing soils.

The experiment conducted by Getachew and Chilot (2003) found that soil $\mathrm{pH}$ has been improved through FYM application. The analysis of soil samples indicated relatively higher $\mathrm{pH}$ levels and nutrient concentrations for plots treated with both FYM and P fertilizer compared to either sole application of FYM or P fertilizer (Table 
4). Similarly, Ano and Ubochi (2007) reported that application of animal manure increased soil pH. The lowest $\mathrm{pH}$ and nutrient content were observed on plots not treated with FYM. The result also shows that the interaction of farmyard manure by phosphorus fertilizer increased faba bean grain yield. The mean grain yields of faba bean increased as the levels of the two interacting factors increased (Table 4).

Similarly, another experiment conducted by Agegnehu et al.(2014) also showed that the application of different soil fertility management treatments affected organic carbon, total N, available P. Also applications of inorganic and organic nutrient sources either alone or in combination had a significant effect on grain yield (Table 4). The results of this study has clearly clarify that if the application rate of fertilizers either as inorganic, organic or the combination of both is at least doubled under farmers' field condition the yield gain will be more than double compared to the control plot and more than 50\% compared to the farmers' applied rate.

In general, integrated use of organic and inorganic nutrient sources could result in significant improvement in the overall condition of the soil as well as agricultural productivity if adopted by producers in the area.

Table 4. Response of ISFM to Grain yield and selected soil physico chemical properties

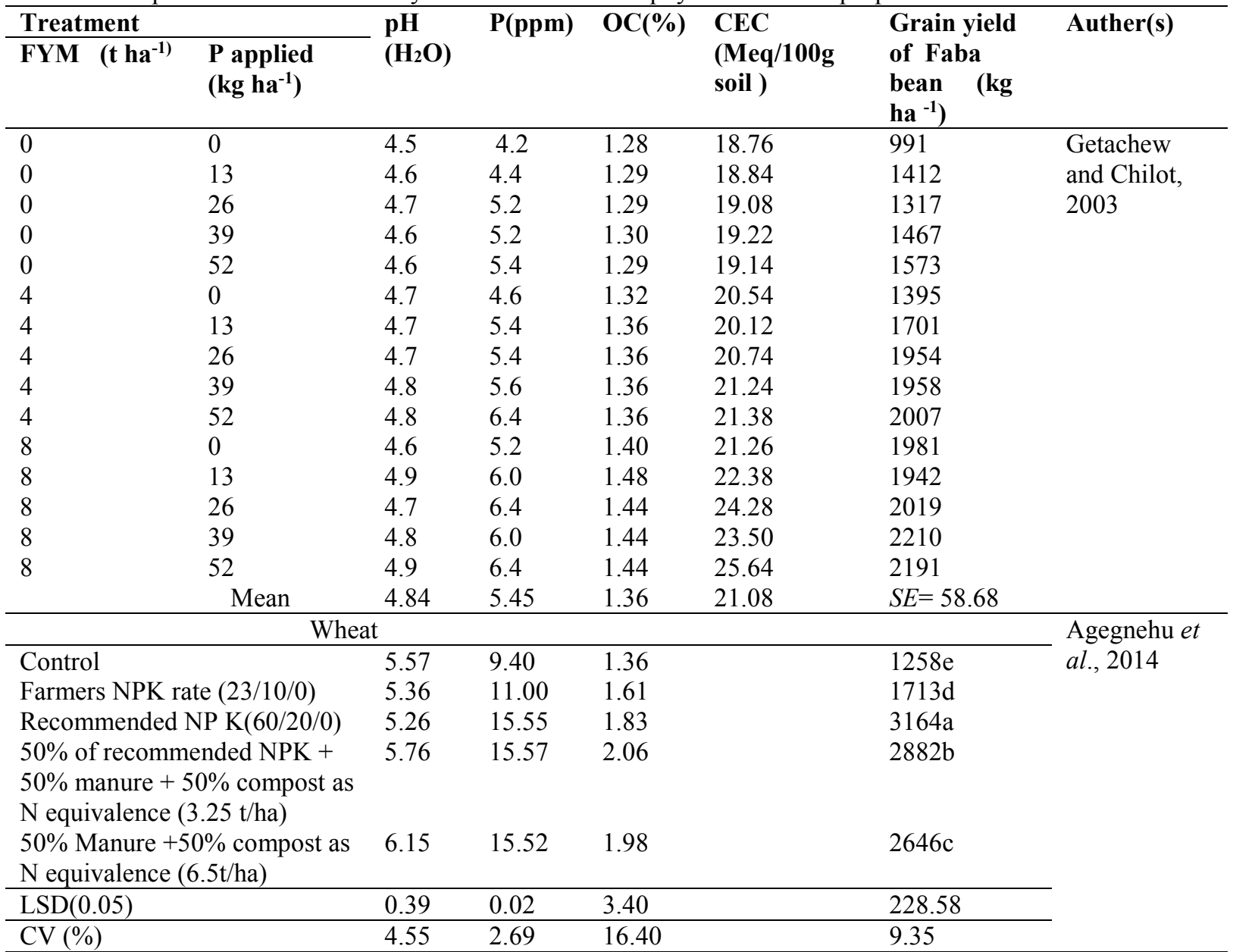

3.3.3. Management of acid soils using acid tolerant crop varieties

Over the past decade, several researchers around the world have focused their efforts on identifying and characterizing the mechanisms employed by crop plants that enable them to tolerate Al toxic levels in acid soils. The two distinct classes of $\mathrm{Al}$ tolerance mechanisms are those that operate to exclude $\mathrm{Al}$ from the root apex and those that allow the plant to tolerate Al accumulation in the root and shoot symplasm (Kochian et al., 2004). A substantial number of plant species of economic importance are generally regarded as tolerant to acid soil conditions. Many of them have their center of origin in acid soil regions, suggesting that adaptation to soil constraints is part of the evolutionary process (Somani, 1996). Although the species as a whole does not tolerate, some varieties of certain species also possess acid soil tolerance.

In the highlands of Ethiopia, barley is mainly grown on Nitisols, where soil $\mathrm{pH}$ is low. This means that barley has been already adapted to acid soil conditions. With this understanding five released barley varieties were evaluated under limed and unlimed condition on acidic soils (Getachew et al., 2019). Barley varieties (HB42 and Dimtu) performed well under limed condition, i.e. yield increments of 366 and 327\%, respectively over the corresponding yields of the same barley varieties under unlimed condition were recorded. In contrast, barley varieties (HB-1307 and Ardu) performed better under unlimed condition, i.e. lower yields of 48 and $49 \%$ 
compared to the corresponding yields of the same barley varieties achieved under limed condition (Table 5).

Another study conducted by Hirpa et al.(2013) reported that soil acidity had significant effect on yield and yield components of common bean genotypes. On average, the genotypes gave higher yield and biomass yield in lime treated soil for all genotypes over no lime application. The magnitude of increase in grain yield and total dry biomass yield due to liming was 25.7 and $27.6 \%$, respectively over the no lime treatment (Table 5).

Table 5. Performance of different genotypes varieties under limed and un-limed conditions

\begin{tabular}{|c|c|c|c|c|c|c|}
\hline \multirow[t]{2}{*}{ Variety } & \multicolumn{2}{|c|}{ Grain yield(kg/ha) } & \multirow{2}{*}{$\begin{array}{l}\text { Yield increament } \\
(\%)\end{array}$} & \multirow{2}{*}{$\begin{array}{l}\text { Kind of } \\
\text { genotypes }\end{array}$} & \multirow{2}{*}{$\begin{array}{l}\text { Study } \\
\text { site }\end{array}$} & \multirow[t]{2}{*}{ Author(s) } \\
\hline & Limed & Unlimed & & & & \\
\hline HB-41 & 1752 & 376 & 366 & \multirow[t]{7}{*}{ Barley } & \multirow[t]{7}{*}{ Endibir } & \multirow{7}{*}{$\begin{array}{l}\text { Getachew Agegnehu } \\
\text { etal.,2019 }\end{array}$} \\
\hline Shegie & 1690 & 982 & 72 & & & \\
\hline Local & 1933 & 1189 & 63 & & & \\
\hline HB-1307 & 2162 & 1459 & 48 & & & \\
\hline Ardu & 2020 & 1355 & 49 & & & \\
\hline Dimtu & 1818 & 426 & 327 & & & \\
\hline $\operatorname{LSD}(0.05)$ & 704 & 1055 & & & & \\
\hline Treatment & GY(t/ha) & $\mathrm{BY}(\mathrm{t} / \mathrm{ha})$ & & \multirow{4}{*}{$\begin{array}{l}\text { Common } \\
\text { bean }\end{array}$} & \multirow[t]{4}{*}{ Nedjo } & \multirow{4}{*}{$\begin{array}{l}\text { Hirpa Legesse et al., } \\
2013\end{array}$} \\
\hline Unlimed & $7.4 \mathrm{~b}$ & $3.6 \mathrm{~b}$ & & & & \\
\hline Limed & $10.3 \mathrm{a}$ & $5.3 \mathrm{a}$ & & & & \\
\hline $\mathrm{CV}(\%)$ & 9.6 & 9.5 & & & & \\
\hline
\end{tabular}

Where, $G Y=$ grain yield, $B Y=$ Biomass yield, $t / h a=$ tonne per hectare $C V=$ coefficient variation.

Hirpa et al.(2013) found that higher absolute grain yield in the lime untreated soil was recorded for the genotypes new BILFA 58, SER176, SEA 5, and Beshbesh. However, Gabisa, Chore, and Anger produced the lowest absolute grain yields on the lime untreated soil (Figure 5). Therefore, Soil acidity problems for common bean production can be overcome by growing genotypes which are adapted to acid soil condition in circumstances where other soil amendment strategies are not readily practical (Hirpa et al., 2013). In general the selection of genotypes/varieties adapted to acid soil conditions to could be a good option for many farmers who cannot afford application of liming material.

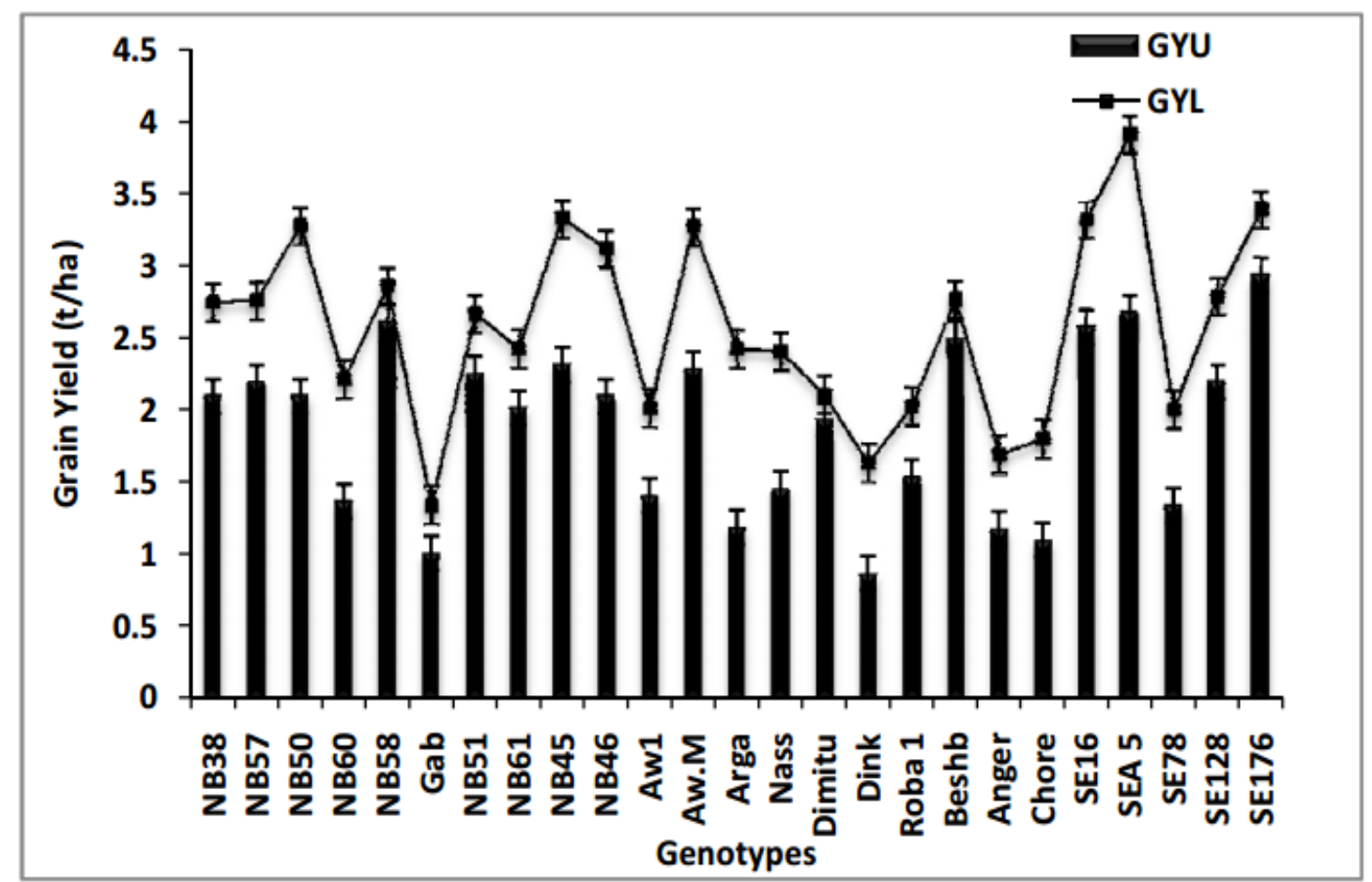

Source: Hirpa Legesse et al., 2013.

Figure 5. Grain yield of common bean genotypes tested for soil acidity tolerance under lime (L) treated and untreated (U) soil

\section{SUMMARY AND CONCLUSION}

Soil acidity is a natural process and their formation depends on specific conditions of climate, topography, vegetation, parent material and high rainfall. It is the main factors that limit and prevent profitable and sustained agricultural productivity in many parts of the world including Ethiopia. The objective of this paper is to review 
the extent of acid soil distributions in Ethiopia, its impact on crop production and management practices. Currently, it is estimated that about $40.9 \%$ of the total arable land of Ethiopia is affected by soil acidity which covers $95 \%$ of the cropped area and contain almost $85 \%$ of the Ethiopian population. From these $27.7 \%$ moderately to weak acids with $\mathrm{pH} 5.8-6.7$ and $13.2 \%$ covered by strong to moderate acidic soils with $\mathrm{pH}$ less than 5.5. Soil acidity can decrease crop yield. According to Ethio SIS, (2014) about $43 \%$ of the Ethiopian arable land is affected by soil acidity of these about $28.1 \%$ of soils in Ethiopia are dominated by strong acid soils ( $\mathrm{pH}$ 4.1-5.5). The detrimental effects of soil acidity normally occur when the soil $\mathrm{pH}$ falls below 4.5. The two fundamental factors that limit the fertility of acid soils: deficiencies of phosphorus $(\mathrm{P})$, calcium $(\mathrm{Ca})$ and magnesium $(\mathrm{Mg}$ ) and phytotoxicity of aluminium (Al). Liming, application of organic materials as ISFM and use of crop varieties tolerant to $\mathrm{Al}$ toxicity are the management options to correct acid soils. Liming has ability to reduce the toxicity effects by lowering their concentrations while increasing the availability of plant nutrients such as $\mathrm{P}, \mathrm{Ca}, \mathrm{Mg}$, and $\mathrm{K}$ in the soil and reducing the solubility and leaching of heavy metals. Organic matter application has a liming effect due to its richness in alkaline cations such as $\mathrm{Ca}, \mathrm{Mg}$ and $\mathrm{K}$, which were liberated from $\mathrm{OM}$ due to mineralization. Soil organic matter increase soil $\mathrm{pH}$ contribute for soil acidity amendments. Soil acidity problems can be also overcome by growing genotypes which are adapted to acid soil condition in circumstances where other soil amendment strategies are not readily practical. Therefore for sustainable agricultural systems within small-scale farming in Ethiopia, liming, use of integrated soil fertlity management, and crop varieties tolerant to $\mathrm{Al}$ toxicity are the the mechanisms used for management of acid soils and should be demonstrated and popularized on farmers field.

\section{REFERENCES}

Abdenna Deressa and Wakene Negassa. 2007. Inventory of soil acidity status in crop lands of Central and Western Ethiopia, ttilisation of diversity in land use systems: Sustainable and organic approaches to meet human needs," Witzenhausen, 9-11.

Abdissa Bekela. 2019. Evaluation of soil acidity and effects of amendments on selected soil properties and yield of maize (Zea Mays 1.) In Ebantu district, Western Highlands of Ethiopia. Phd Dissertation. Haramaya University.

Achalu Chimdi, Heluf Gebrekidan, Kibebew Kibret and Abi Tadesse. 2012. Response of barley to liming of acid soils collected from different land use systems of Western Oromia, Ethiopia. Journal of Biodiversity and Environmental Sciences, 2(7): 1 - 13.

Agegnehu G, vanBeek C and Bird M. 2014. Influence of integrated soil fertility management in wheat and tef productivity and soil chemical properties in the highland tropical environment. Journal of Soil Science and Plant Nutrition, 2014, 14.

Agegnehu, G., Fikre, A., and Tadesse, A. 2006. Cropping systems, soil fertility and crop management research on food legumes in the Central Highlands of Ethiopia. In "A review of major achievements of a decade" (K. Ali, G. Keneni, S. Ahmed, R. S. Malhotra, S. Beniwal and K. Makkouk, eds.), pp. 135-145. ICARDA, Addis Ababa, Ethiopia.

Andric, L., Rastija, M., Teklic, T. and Kovacevic, V. 2012. Response of maize and soybeans to liming. Turkish Journal of Agriculture and Forestry, 36: 415 - 420.

Angaw Tsigie and Desta Beyene. 1988. Summary of lime trials on different yield of crops. In: Desta Beyene (ed.), Proceedings of Soil Science Research in Ethiopia. Feb., 1996. Addis Ababa, Ethiopia.

Ano, A.O. and C.I. Ubochi. 2007. Neutralization of soil acidity by animal manures; mechanism of reaction. African Journal of Biotechnology, 6: 364-368.

Baligar, V.C, R.E .Schaffert, H.L .Santos, G.VE. Pitta, AF. B. Filho, H. D. Santos. 1993. Soil aluminium effects on uptake, influx and transport of nutrients in sorghum genotypes. Plant and Soil, 150: 271-277.

Barber, S. A. 1984. Liming materials and practices. In "Soil Acidity and Liming" (F. Adams, Ed.), $2^{\text {nd }}$ Ed. pp. 171-209. ASA-CSSA-SSSA, Madison, Wisconsin.

Bohn, H.L, B.L. McNeal and G.A. O'Connor. 2001. Soil chemistry, $3^{\text {rd }}$ ed. John Wiley and Sons, Inc., New York. $307 \mathrm{p}$.

Brady, N.C. and R.R. Weil. 2002. The nature and properties of soils, $13^{\text {th }}$ ed. Prentice- Hall Inc., New Jersey, USA. 960p.

Brady N.C. and Weil, R.R. 2014. The nature and properties of soils. $14^{\text {th }}$ ed. Prentice- Hall Inc., New Jersey, USA.

Brown,J.R. and J.Stecker. 2003. Liming in Missouri in the $20^{\text {th }}$ century. In Missouri soil fertility and fertilizers research update 2003. University of Missouri-Colombia, special reports ,548:1-81.

Buni, A. 2014. Effects of liming acidic soils on improving soil properties and yield of haricot bean. Journal. Environ. Anal. Toxicol. 5, 1-4.

Cheng, M., J. Jiyun and H. Shaowen. 1999. Release of native and non-exchangeable soil potassium and adsorption in selected soils of North China. Better Crops Int.,13: 3-5. 
Dessalegn Tamene, Bekele Anbesa, Getahun Dereje and Bogale Walelign. 2018. Response of sorghum and soybean to split application of lime. EIAR, Addis ababa ISBN: 978-99944-66-52-8, p138.

Effiong GS and Okon I. 2009. Evaluation of mollusk shell as liming materials for acid sands of Akawa Ibom State, Southeastern Nigeria. Soil Science Society of Nigeria Journal. 2009;25:25-32.

Essington, M.E. 2004. Acidity in soil minerals. In soil and water chemistry, pp.473- 497. CRC. Press LLC.

Eswaran, H., Reich P. and Beinroth, F. 1997. Global distribution of soils with acidity. In: plant-soil interactions at low pH. Moniz, A.C (eds.). Brazilian Soil Science Society. 159 - 164.

Ethio SIS. 2014. Soil fertility mapping and fertilizer blending. Agricultural Transformation Agency (ATA) Report, Ethiopia soil information system (Ethio SIS). Ministry of Agriculture, Addis Ababa.

Eylachew Zewdie. 1987. Study on phosphorus status of different soil types of Chercher highlands, South-Eastern Ethiopia. PhD Thesis. University of Jestus Liebig, Germany. 168p.

Fageria, N.K. and V.C. Baligar, 2003. Fertility management of tropical acid soils forsustainable crop production, 359 - 385. In: Z. Rengel, Editor, Hand book of soil acidity. University of Western Australia, Perth, Western Australia, Australia.

Fageria NK, Baligar VC, Zobel RW .2007. Yield, nutrient uptake and soil chemical properties as influenced by liming and boron application in a no-tillage system. Communication in Soil Science and Plant Analysis, 38: $1637-1652$.

Fageria, N.K. and Baligar, V.C. 2008. Improving nutrient use efficiency of annual crops in Brazilian acid soils for sustainable crop production. Communications in Soil Science and Plant Analysis, 32: 13031319.

Fageria, N. K, 2009. The use of nutrients in crop plants. CRC Press, New York. 430pp.

FAO. 2003. State of the World's Forests. Rome.ftp.fao.org/docrep/fao/005/y7581e/.

FAO. 2015. Declaration of the world summit on food security, Rome. www.fao.org/wsfs/world-summit.en.

Getachew Agegnehu, Chilot Yirga,and Teklu Erkossa. 2019. Soil acidity management. Ethiopian Institute of Agricultural Research (EIAR). Addis Ababa, Ethiopia

Gupta, K. P. 2000. Hand book of soil fertilizer and manure. Agro-Botanica, New Delhi, India. 380p.

Havlin, L.J., D.J. Beaton, L.S. Tisdale and L.W. Nelson. 1999. Soil fertility and fertilizers: An introduction to nutrient management. $6^{\text {th }}$ ed. New Jersey. Prentice Hall, Inc.

Hawaiian acid soils, Journal of Plant Nutrition, vol. 27, no. 2, pp. 261-274.

He, Z.L., A.K. Alva, D.V. Calvert, Y.C. Li and D.J. Banks. 1999. Effects of fertilization of grape fruit trees on soil acidification and nutrient availability in a Riviera Fine Sand. Plant Soil, 206: 11-19.

Hirpa Leggese, Nigussie-Dechassa, Setegn Gebeyehu, Geremew Bultosa and Firew Mekbib. 2013. Response to soil acidity of common bean genotypes (Phaseolus vulgaris L.) under field conditions at Nedjo, Western Ethiopia. Science, Technology and Arts Research Journal, 2: 03-15.

Hue NV. 2004. Responses of coffee seedlings to calcium and zinc amendments to two Hawaiian acid soils. Journal of Plant Nutrition, vol. 27, no. 2, pp. 261-274.

ISRIC. 1990. Guidline for soil profile description $3^{\text {rd }}$ ed., review. FAO, Rome.

Kisinyo PO, SO Gudu, CO Othieno, JR Okalebo, PA Opala, JK Maghanga, JJ Agalo, WK Ng'etich, JA Kisinyo, RJ Osiyo, AO Nekesa, ET Makatiani, DW Odee, and BO Ogola. 2012. Effects of lime, phosphorus and rhizobia on sesbania sesban performance in a Western Kenyan acid soil. African Journal of Agricultural Research, 7 (18): 2800 - 2809.

Kochian, L.V., Hoekenga, O.A. and Piners, M.A. 2004. How do crop plants tolerate acid soils: Mechanism of aluminum tolerance and phosphorus efficiency. Annual Review of Plant Biology 55: 459-493.

Langer, H., M. Cea., G.Curaqueo.and F.Borie. 2009. Influence of aluminum on the growth and organic acid exudation in alfalfa cultivars grown in nutrient solution. Journal of plant nutrition, 32:618-628.

Maddonni, G. A, S. Urricariet, C.M. Ghersa and R.S. Lavado. 1999. Assessing soil fertility in the rolling Pampa, using soil properties and maize characteristics. Journal of Agricultural Research Science, 91:280-286.

Marschner, H. 2011. "Marschner's mineral nutrition of higher plants," Academic press, London.

Mattsumoto, H. 2002. Plants under aluminum stress: toxicity and tolerance. In plant roots the hidden half, ed.y. waisel, A. Eshel, U. Kafkafi , and M.Dekkur, pp.821- 838. Inc.Newyork.

McBride, M.B. 1994. Environmental chemistry of soils. Oxford University Press. New York.

Menzies N. W., 2003. Toxic elements in acid soils: Chemistry and measurement. 267-296. In: Zdenko Rengel (ed.) Handbook of Soil Acidity. University of Western Australia, Perth,Western Australia, Australia.

Mesfin Abebe. 1996. The challenges and future prospects of soil chemistry in Ethiopia. pp. 78-96. In: Teshome Yizengaw, Eyasu Mekonnen and Mintesinot Behailu (eds.). Proceedings of the $3^{\text {rd }}$ Conference of the Ethiopian Society of Soil Science (ESSS). Feb. 28-29, 1996. Addis Ababa, Ethiopia.

Mesfin Abebe. 1998. Natures and management of Ethiopian soils. Alemaya University of Agriculture, Ethiopia. P. 272.

Mesfin Abebe. 2007. Nature and management of acid soil in Ethiopia. Haramaya University. Haramaya, Ethiopia. 99pp 
Moges T, Melese A, Tadesse G. 2018. Effects of lime and phosphorus fertilizer levels on growth and yield components of malt barley (Hordeum distichum L.) in Angolelana Tera District, North Shewa Zone, Ethiopia. Journal of Advanced Agricultural Research, 8(6):582-589.

Nyamangara, J. 2001. Nitrogen leaching and recovery studies in a sandy soil amended with cattle manure and inorganic nitrogen fertilizer under high rainfall conditions. Ph.D. Diss.Univ. Zimbabwe, Mount pleasent, Zimbabwe.

Robarge W.P., 2008. Acidity. In: Encyclopedia of Soil Science, Encyclopedia of Earth Sciences Series (Ed.: Ward Chesworth). 860pp.

Saikhe, H., C. Varadachari and K. Ghosh. 1998. Changes in carbon, N and P levels due to deforestation and cultivation. A Case study in Simplipal National Park, India. Plant Soil, 198:137-145

Sanchez, P.A. and Salinas, J.G. 1981. Low input technology for managing Oxisols and Ultisols in Tropical America. Journal of Advanced Agronomy, 34:279-406.

Sanchez, P.A., Shepherd, K.D., Soule, M.J., Place, F.M., Buresh, R.J., Izac, A.M., Mokwunye, A.U., Kwesiga, F.R., Ndiritu, C.N. and Woomer, P.L., 1997. Soil fertility replenishment in Africa: an investment in natural resource capital. In: Buresh R.J., Sanchez, P.A. and Calhoun, F. (Eds.). Replenishing soil fertility in Africa. Soil Science Society of American Journal. Special Publication No. 51, 1-46. Madison, Wisconsin, USA.

Schlede, H. 1989. Distribution of acid soils and liming materials in Ethiopia. Ethiopian Institute of Geological Surveys, Ministry of Mines and Energy. Addis Ababa, Ethiopia

Sivaguru M and Horst, W. J. 1998. The distal part of the transition zones is the most aluminum-sensitive apical root zone of maize. Plant Physiology. 116, 155-163.

Somani, L.1996. "Crop production in acid soils," $1^{\text {st }}$ Ed. Agrotech Publishing Academy, New Delhi.

Sumner, M. E., and Noble, A. D., 2003. Soil acidification: The world story. In: Rengel. Z, (eds). Handbook of Soil Acidity. Pp. 1-28. Marcel Dekker, New York

Taye Bekele. 2007. An over view of acid soils their management in Ethiopia paper presented in the third international workshop on water management (Wterman) project, September, 19-21,2007, Haromaya, Ethiopia.

Tigist Addisu. 2017. Soybean (Glycine max L.) response to lime and vermicompost amelioration of acidic nitisols of Assossa, North Western Ethiopia. MSc Thesis Haramaya University, Haramaya, Ethiopia

United Nations Environment Programme (UNEP). 2004. The Scientific and Technical Advisory Panel of the GEF "Review of emerging, innovative technologies for the destruction of POPs and the identification of promising technologies for use in developing countries.

Vesterager JM. 2008. Effects of cropping history and phosphorus source on yield and nitrogen fixation in sole and intercropped cowpea-maize systems, nutrient cycling in Agro ecosystems, vol. 80 (pg. 61-73)

Von Uexküll, H., and Mutert, E. (1995). Global extent, development and economic impact of acid soils. Plant Soil, 171, 1-15.

Wang, J., Raman, H., Zhang, G. Mendham, N. and Zou,M. 2006. Aluminum tolerance in barely (Horidium vulgarie L.): Physiological mechanisms, genetics and screening methods. Journal of Zhejiang University Science. 7: 769-787.

Wassie Haile and Shiferaw Boke. 2009. Mitigation of soil acidity and fertility decline challenges for sustainable livelihood improvement: research findings from southern region of Ethiopia and its policy implications.

World Bank, 1995. Staff Appraisal Report. National Fertilizer Sector Project, Ethiopia, Report No. 13722-ET.

Yang B., D. Eticha, A. Albacete, M. Rao, T. Roitsch and J. Horst, 2012. Physiological and molecular analysis of the interaction between aluminium toxicity and drought stress in common bean (Phaseolus vulgaris). Journal of experimental botany, 63: 3109-3125.

Yao, M. K., Angui, P. K., Konaté, S., Tondoh, J. E., Tano, Y., Abbadie, L., and Benest, L. 2010. Effects of land use types on soil organic carbon and nitrogen dynamics in mid-west Côte d'Ivoire. European Journal of Science and Research, 40: 211-222. 